\title{
o império da fiscalidade: notas sobre a produção colonial ${ }^{\star}$ the governance of taxation: notes on the colonial production
}

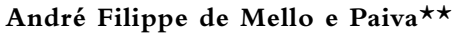 \\ Faculdade de Filosofia, Letras e Ciências Humanas, Universidade de São Paulo, São Paulo, São \\ Paulo, Brasil
}

\section{RESUMO}

O artigo tem por objeto a produção colonial estudada pelo autor em sua dissertação de mestrado defendida no final de 2016. O trabalho teve como foco principal o estudo das conjunturas fiscais no Atlântico português por meio da a nálise dos contratos régios arrematados no Conselho Ultramarino. O recorte cronológico se iniciou no ano de 1720, com a centralização das arrematações dos contratos no Conselho Ultramarino e a crescente exploração do ouro, e teve como marco final o ano de 1807, com o fim do exclusivo metropolitano. A pesquisa analisa séries inéditas dos dízimos e dízimas das principais praças coloniais (Bahia, Pernambuco, Rio de Janeiro e Minas Gerais).

Palavras-chave: Contratos. Conjunturas econômicas. Império português. Século XVIII. Conselho Ultramarino.

\begin{abstract}
The article aims at the colonial production studied by the author in his master dissertation defended at the end of 2016. The main focus was the study of fiscal conjunctures in the Portuguese Atlantic by means of the analysis of the royal contracts awarded to the Overseas Council. The chronological cut began in the year 1720, with the centralization of the contracts in the Overseas Council and the increasing exploitation of gold, and had as its final mark the year 1807, with the end of the exclusive metropolitan. The research analyzes unpublished series of church tithes and other tithe taxes of the main colonial squares (Bahia, Pernambuco, Rio de Janeiro and Minas Gerais).
\end{abstract}

Keywords: Contracts. Economic conjunctures. Portuguese Empire. Eighteenth century. Overseas Council.

* Este artigo, e a dissertação que o originou, não seriam possíveis sem o fomento da CAPES, assim como o Estágio de Pesquisa em Portugal proporcionado pela Cátedra Jaime Cortesão e pelo Instituto Camões, a que agradeço imensamente. Aproveito também para registrar minha gratidão aos professores que compuseram a banca de defesa da dissertação, Angelo Carrara e Rodrigo Ricupero. Agradeço também os comentários do professor Roberto Borges Martins na ocasião da apresentação deste trabalho no XII CONGRESSO BRASILEIRO DE HISTÓRIA ECONÔMICA, realizado em Niterói, em agosto de 2017.

Submetido: 14 de novembro de 2017; aceito: 2 de janeiro de 2018.

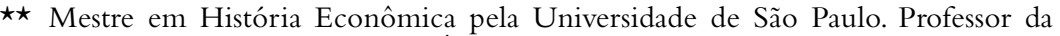
Fundação Escola de Comércio Álvares Penteado e do Centro de Ensino Superior Strong. Professor monitor no INSPER.E-mail: andrepaiva@outlook.com.br 
Neste artigo, pretendemos discutir as conjunturas econômicas do século XVIII português por meio de séries relativas à produção. $\mathrm{O}$ objetivo é analisar o que poderíamos chamar de "indicadores gerais" da economia colonial: as curvas nos preços do açúcar, nos preços do tabaco, na produção do ouro e na importação de escravos.

\section{1. "A civilização do açúcar"1}

Gênero que perpassa todo o período colonial, a comparação dos preços do açúcar em diferentes praças pode oferecer importante indicativo para percebermos os movimentos da economia. Produto mais representativo nas rendas coloniais até a mineração, o açúcar permaneceu como um dos mais importantes gêneros na pauta de exportações brasileiras, até o final do século XVIII. Mesmo com o processo de diversificação agrícola, o produto foi caracterizado na faixa de média lucratividade por Jobson Arruda ${ }^{2}$.

A organização da cultura do açúcar, dada em latifúndios com altos patamares de produção, alavancava os níveis de renda dos setores dominantes, do ponto de vista econômico, da colônia. Além disso, foi a principal responsável na movimentação de atividades auxiliares, como a produção de farinhas ${ }^{3}$ por exemplo, além de estimular a vinda da mão de obra escrava africana para as plantações brasileiras. A historiografia recente tem demonstrado que a produção de alimentos nos próprios engenhos era insuficiente para o sustento dos plantéis, e os produtos

1 Tomamos emprestado o título do trabalho da professora Vera Lucia Amaral Ferlini, publicado em 1984 sob a série Tudo é História, v. 88, da Editora Brasiliense.

2 A empresa açucareira chegou a representar uma lucratividade na casa dos $40 \%$, se considerarmos o açúcar branco, perdendo apenas para o negócio dos couros $(53,8 \%)$ e algodão (64,5\%), porém, estes com produção muito menor e mais localizada no final do século XVIII. No caso dos couros, ao menos desde meados do século XVIII já se observam remessas não insignificantes na região amazônica. "A saber, café $(84,68 \%)$, arroz $(101,29 \%)$ e produtos com presença secular no trânsito comercial: cacau $(99,7 \%)$ e tabaco (103,74\%).” (Arruda, 2014, p. 711.)

3 A farinha de mandioca era demandada para a alimentação em geral e também para o plantel de escravos, em alguns casos servindo até para a exportação, como indica Pinto (1979, p. 188). A carestia de víveres desse tipo foi abordada por Menz (2013, p. 42-44). 
para subsistência eram comprados no mercado, gerando demanda para outras atividades.

Paulatinamente, as terras pouco aptas para a produção de açúcar eram ocupadas para a produção de alimentos: roças de mandioca e outros produtos agrícolas nas zonas mais próximas do litoral, e de gado bovino no sertão.Também o fornecimento de escravos para os engenhos gerava outras atividades econômicas, como a construção naval na Bahia, além de alimentos que eram demandados para as tripulações e para os cativos. Em todas essas ocupações, utilizava-se amplamente a mão de obra, gerando uma alta demanda por trabalhadores escravizados oriundos da costa da África (cf. Schwartz, 2001; Barickman, 2003; Lapa, 1968).

O açúcar era o principal elemento de ascensão social e deformação das elites nas cidades de Salvador e Recife, que assumiam os cargos militares e administrativos na colônia. Ou seja, o açúcar - muito além de uma mera atividade econômica - sobredeterminava as relações sociais e políticas na colônia. Era um elemento agregador dos aspectos econômicos, políticos e sociais. Além de garantir lucros e ascensão social, era uma atividade que tinha um efeito multiplicador sobre a economia local. O estímulo também era sentido em outras localidades, como nas capitanias do Sul ${ }^{4}$, onde "gradativamente, o açúcar foi imprimindo às terras e aos homens uma nova configuração, assentando as bases de um mundo de senhores e escravos que o café se encarregaria de consolidar" (Ferlini, 2010, p. 185). Em finais do século XVIII, animados pela mudança da capital para o Rio de Janeiro e com o crescimento da população dos escravos libertos, observa-se "o desenvolvimento de uma infraestrutura de estradas melhoradas, instalações portuárias e cabotagem, que viabilizaram e tornaram lucrativo o abastecimento do mercado carioca" (Schwartz, 2001, p. 140).

Observemos os preços do açúcar em Lisboa, ao longo do século XVIII, de maneira a alcançar um primeiro indicador do movimento geral da economia:

4 "De certa maneira, podemos afirmar que, no caso do Rio de Janeiro, o tráfico criou o açúcar, incrementando sua dinâmica econômica desde o final do XVII. Cana para aguardente, aguardente para escravos, escravos para cana e para a mineração - a produção açucareira fluminense inseriu-se num esquema bastante próximo da autoestimulação.” (Ferlini, 2010, p. 201-202.) 
Gráfico 1 - Preço do açúcar branco em Lisboa (réis/kg), 1720-1807

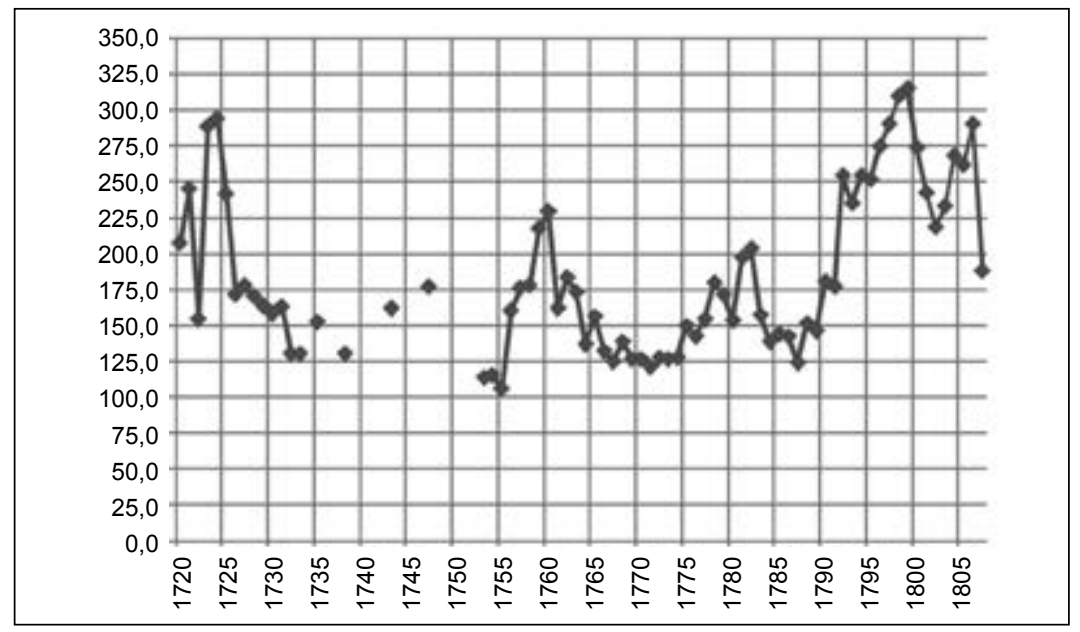

Fonte: PWR.

Gráfico 2 - Preço do açúcar branco em Lisboa (réis/kg), 1720-1762

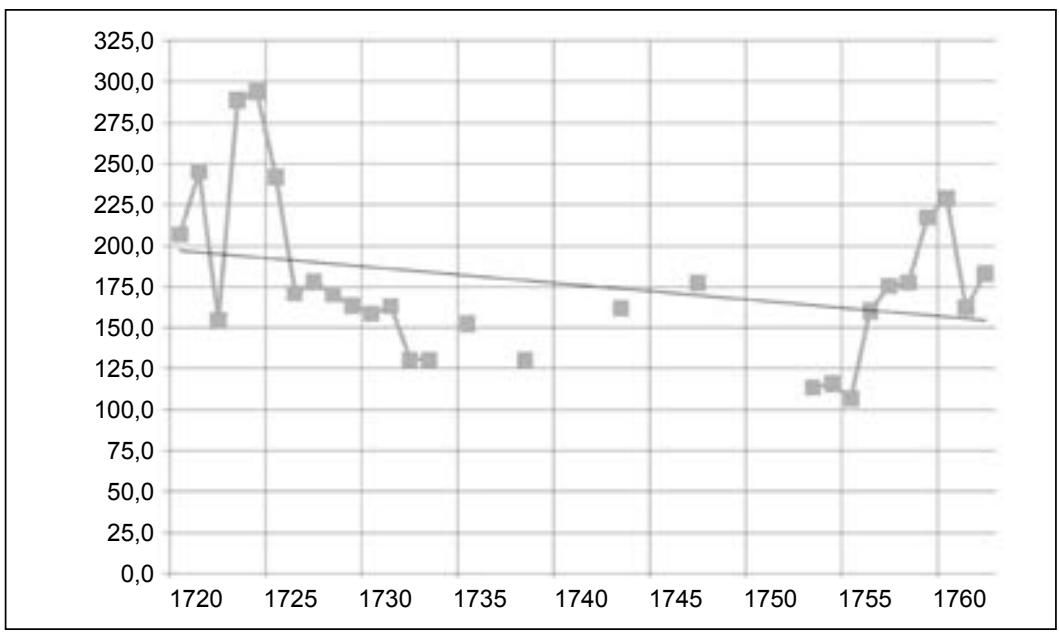

Fonte: PWR.

Os preços pagos em Lisboa pelo açúcar branco sofrem grande variação ao longo do século XVIII, atingindo seu valor máximo em 1799, valendo 315,3 réis o quilo, e seu ponto mais baixo no ano de 1755 , o 
ano do terremoto, com 106,5 réis o quilograma. Para que possamos analisar de forma mais detida, dividiremos o gráfico em duas partes, tomando como marco divisório a criação do Erário Régio em dezembro de 1761, quebrando a série no ano de 1762. Dada a ligação de nosso trabalho com a fiscalidade e a organização das rendas do Império português, pensamos ser uma escolha adequada utilizar esse marco institucional como divisão.

Ainda que tenhamos valores acima dos 200 réis por quilograma entre os anos de 1720 e 1725 , em grande parte do período analisado os valores estiveram abaixo desse patamar. Houve 15 apontamentos entre 150 réis e 200 réis; 6 entre 100 réis e 150 réis e 1 recuperação acima dos 200 réis, após grande queda ocorrida nos anos 1750 , quando atingiu seu preço mais baixo. Por mais que haja algumas lacunas nessa parte da série, a tendência entre 1720 e 1762 é de baixa nos preços do açúcar. Analisemos o mesmo período a partir dos dados compilados por Dauril Alden e ajustados por Stuart Schwartz, agora para a Bahia.

Gráfico 3 - Preço do açúcar branco na Bahia (réis/kg), 1720-1762

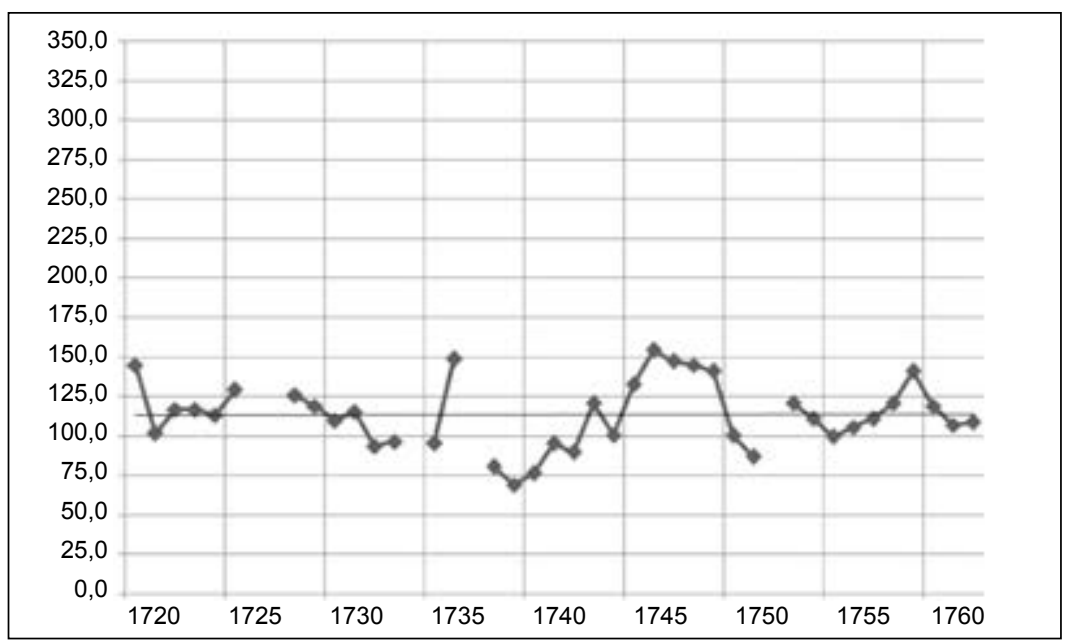

Fonte: GPIHG.

Notadamente, os preços do açúcar branco aferidos na Bahia diferem relativamente daqueles que encontramos em Lisboa, dado o custo do transporte entre as cidades, apontando uma tendência à estagnação.Ainda 
que possamos identificar uma leve recuperação de 1740 até 1746 , seguido por nova queda até 1751. A seguir, analisemos o Gráfico 4, que conta com esses dados, porém transformados em índices, tendo como marco o ano de $1762^{5}$ :

Gráfico 4 - Preço do açúcar branco - Bahia versus Lisboa, 1720-1762 (índice 1762 = 100)

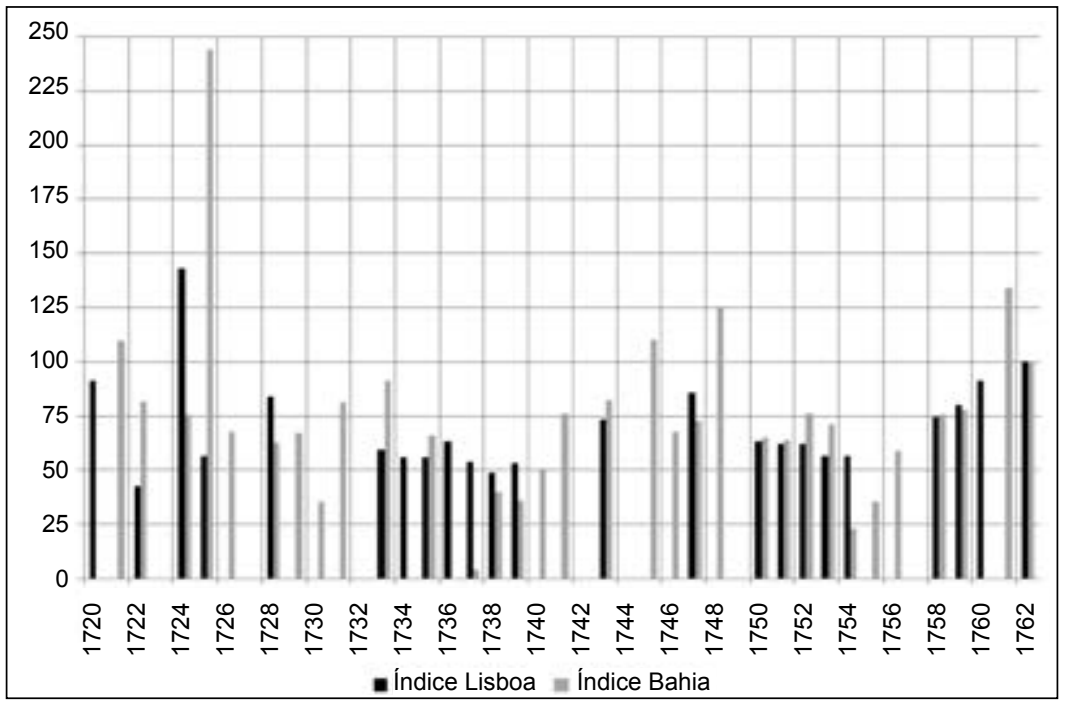

Fonte: PWR, GPIHG.

Optamos pela apresentação desses dados em índices para evidenciar uma característica bastante interessante: podemos notar uma confluência nas variações dos valores na praça colonial e na metrópole. Claro que em alguns anos, especificamente 1722, 1724, 1725 e 1763, existe uma diferença na flutuação, mas que podemos classificar como algo pontual, já que em todos os anos restantes a oscilação dos preços tende a acompanhar seu correspondente da outra ponta do Atlântico com alguma similaridade.

5 Para essa situação, seguimos a divisão que escolhemos para facilitar nossas análises, levando em conta a data de criação do Erário Régio. A opção de transformação dos valores em índices vem no sentido de podermos apreender de forma mais proveitosa o comportamento das curvas geradas pela variação desses valores, independentemente de seus valores nominais aferidos. 
Já que não dispomos de dados para a Bahia a partir do ano de 1768, utilizaremos então para comparação os preços do gênero aferidos no Rio de Janeiro, a partir do ano de 1763 (Gráfico 5). Nosso propósito é o de complementar nossa análise da flutuação dos preços do açúcar, para verificar se há de fato uma conjuntura comum entre os valores encontrados na colônia e na metrópole:

Gráfico 5 - Preço do açúcar branco no Rio de Janeiro (réis/kg), 1763-1807

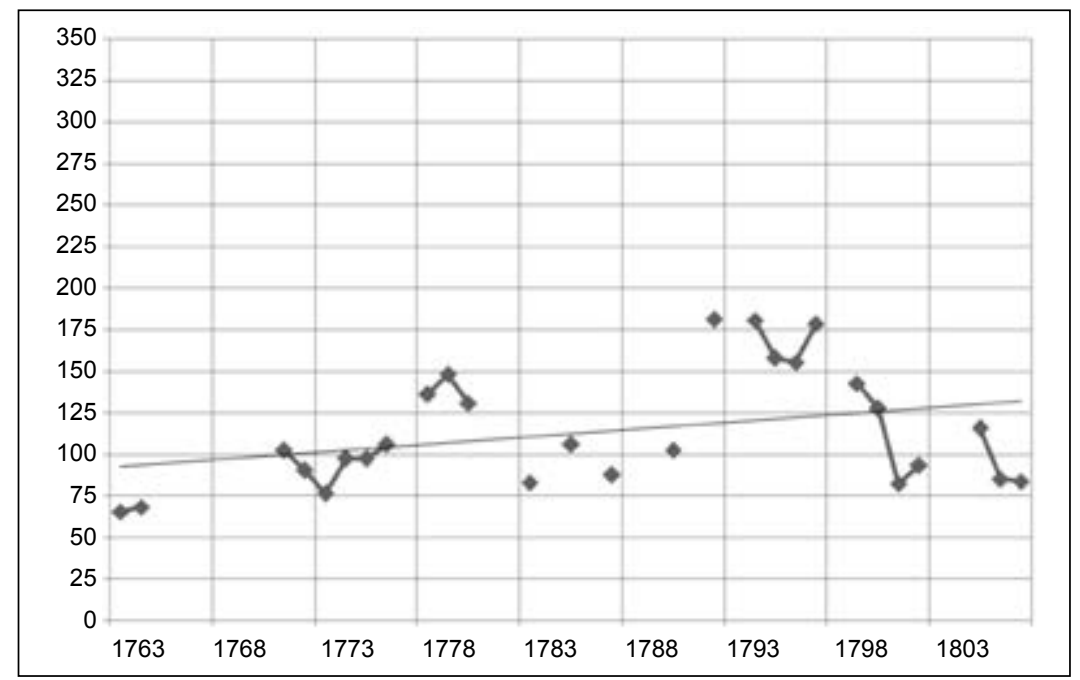

Fonte: Johnson Jr. (1973, p. 274-276).

Apesar de algumas lacunas na fonte, o primeiro movimento que podemos perceber é uma variação negativa em meados da década de 1770 , seguida de recuperação que se anunciava a partir de 1773, que se sustenta até os 148 réis por quilograma no ano de 1779. Como demonstrado no Gráfico 6, após um período de estagnação nos preços de Lisboa, uma recuperação destes é sentida a partir do ano de 1774. Na virada para a década seguinte, ambas as series apontam para uma leve queda. Após algumas variações nos poucos lançamentos que possuímos de 1780 a 1794, o movimento que pode ser mais bem apreendido está nos quatro lançamentos seguintes, que mostram variações que são sucedidas por uma grande queda nos preços até 1801, quando retorna aos valores na casa dos 80 réis, movimento de queda bastante semelhante ao que foi 
aferido para a metrópole no período de 1799-1802, quando se desvaloriza em quase 100 réis no preço.

Gráfico 6 - Preço do açúcar branco em Lisboa (réis/kg), 1763-1807

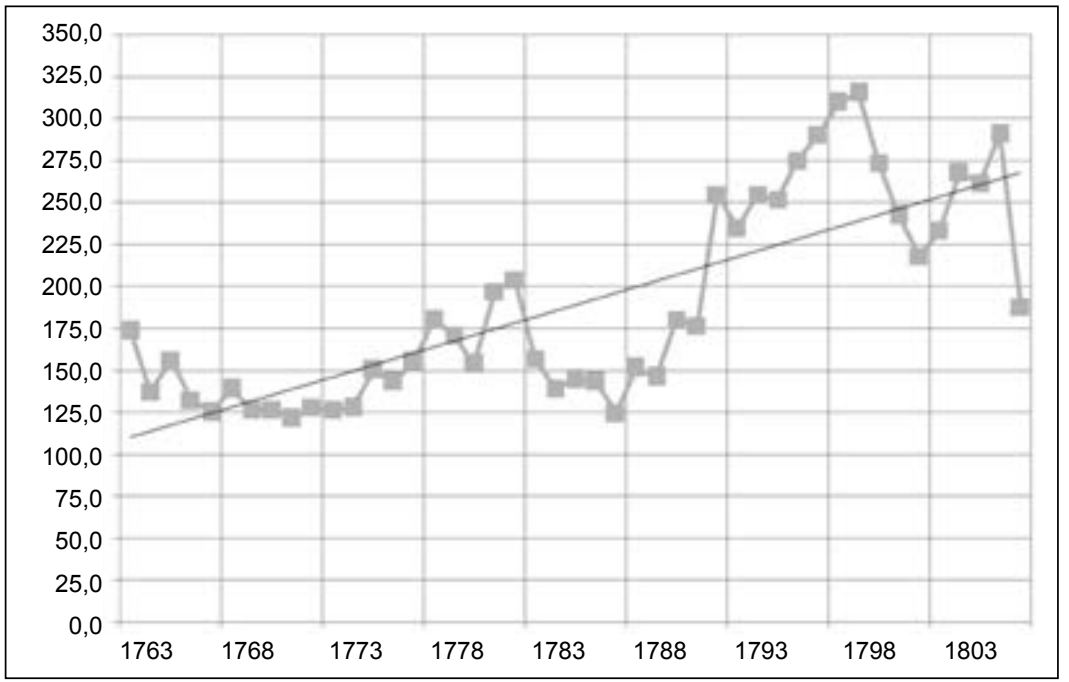

Fonte: PWR.

No Gráfico 6 podemos observar a clara tendência de alta nos preços em Lisboa. Alguns movimentos distintos podemos depreender da série: 1763-1782, estagnação com viés de alta; 1782-1787, breve período de queda; 1787-1799, valorização constante, partindo de 124 réis e chegando em 315,3 réis, ou seja, uma valorização de $254 \%$.

O que a comparação da metrópole com o caso do Rio de Janeiro pode nos mostrar (Gráfico 7), mais do que movimentos completamente coincidentes, são os momentos-chave análogos de queda/valorização dessas duas praças. A integração que a economia açucareira fluminense passa a experimentar nessa segunda metade do Setecentos pode passar a ser percebida nessas variações dos preços. Antes ligada apenas ao abastecimento de Minas Gerais e ao serviço do transporte do ouro, a economia do Rio de Janeiro, impulsionada por essas atividades, se relacionará de forma mais direta ao mercado atlântico e, dessa forma, ao tráfico de escravos, conforme abordaremos ao longo do trabalho. 
Gráfico 7 - Preço do açúcar branco - Rio de Janeiro versus Lisboa, 1763-1807 (índice $1763=100)^{\star}$

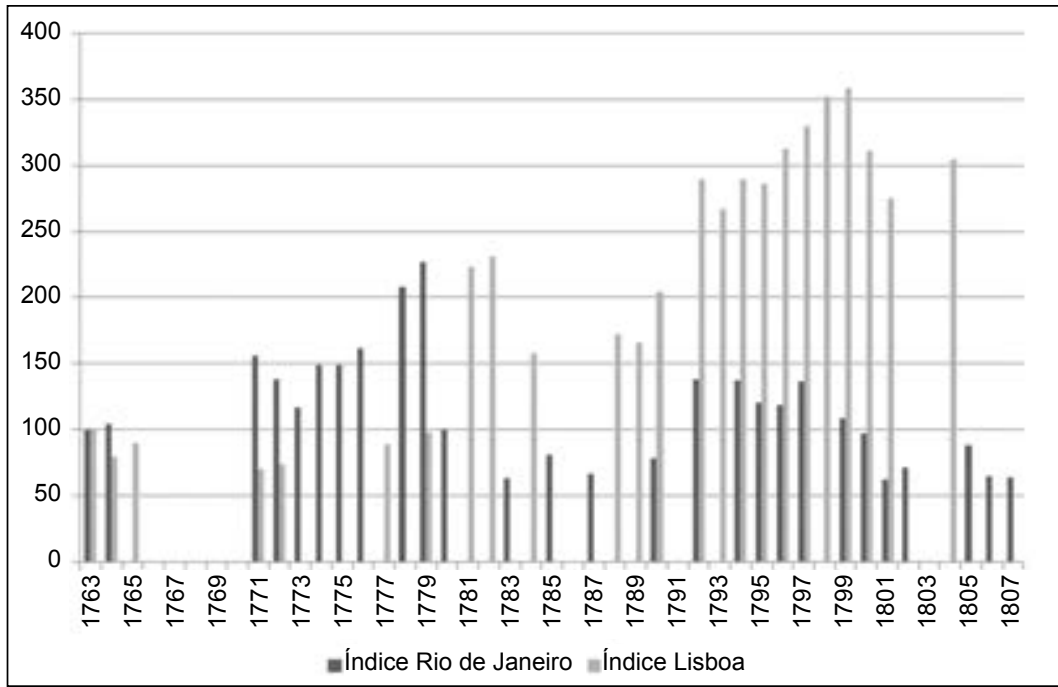

Fonte: Johnson Jr. (1973, p. 274-276), PWR.

* Apenas neste gráfico utilizamos como marco do índice o ano de 1763 , pois não possuímos dados relativos ao Rio de Janeiro para o ano de 1762.

Tendo em vista o caráter exportador da produção açucareira e sua interconexão com os mercados mundiais, a seguir apresentamos um gráfico com os preços gerais do açúcar nas principais praças europeias, Lisboa, Londres e Amsterdã, para que possamos observar se há uma estrutura de preços mundial do gênero. Considerando a diferença nas tendências entre a primeira e a segunda metade do século e a organização de nossas fontes ${ }^{6}$, apresentamos os dados em três partes, começando com uma visão geral (Gráfico 8, para todo o período; Gráfico 9, de 1720 a 1762; e Gráfico 10, de 1763 a 1807).

6 Para a primeira parte, até 1762, utilizamos para os preços de Lisboa os dados de Dauril Alden, ajustados por Stuart Schwartz e convertidos para o equivalente em prata pelo GPIHG. Para o segundo, utilizamos os dados disponibilizados pelo PWR. 
Gráfico 8 - Preço do açúcar em Londres, Lisboa e Amsterdã (gramas de prata/kg), 1720-1807

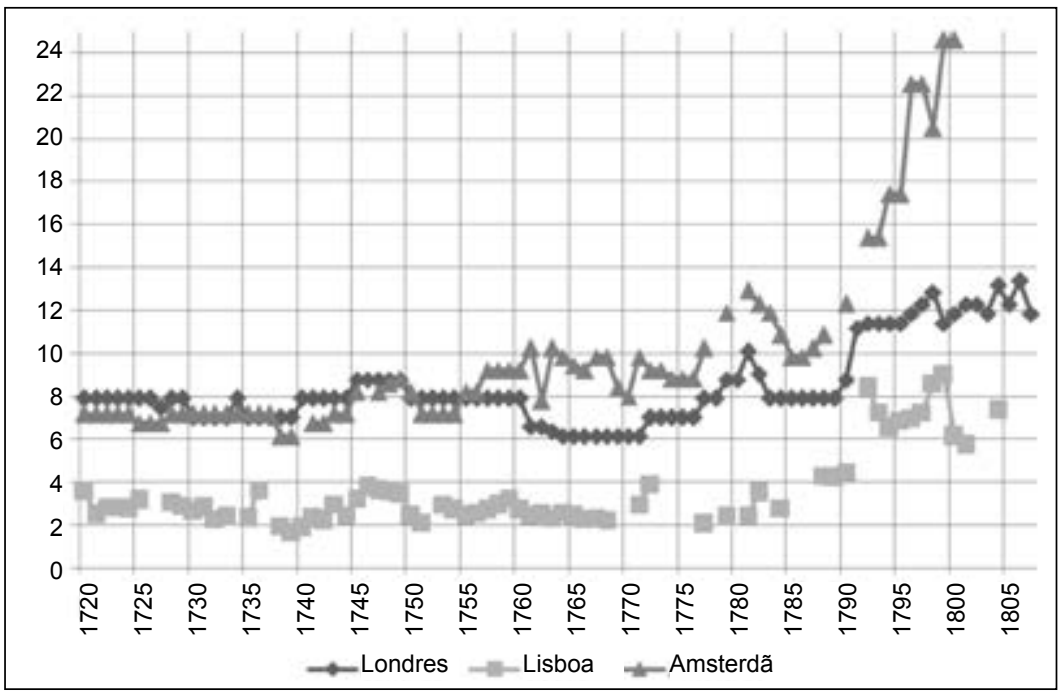

Fonte: PWR, GPIHG.

Gráfico 9 - Preço do açúcar em Londres, Lisboa e Amsterdã (gramas de prata/kg), 1720-1762

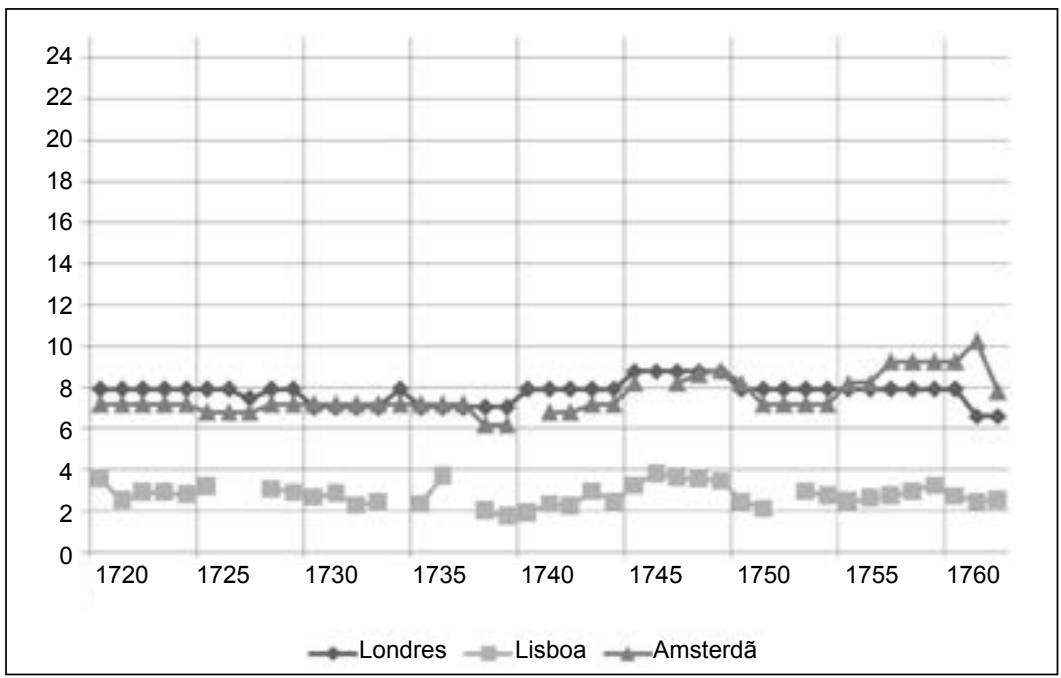

Fonte: PWR, GPIHG. 
Gráfico 10 - Preço do açúcar em Londres, Lisboa e Amsterdã (gramas de prata/kg), 1763-1807

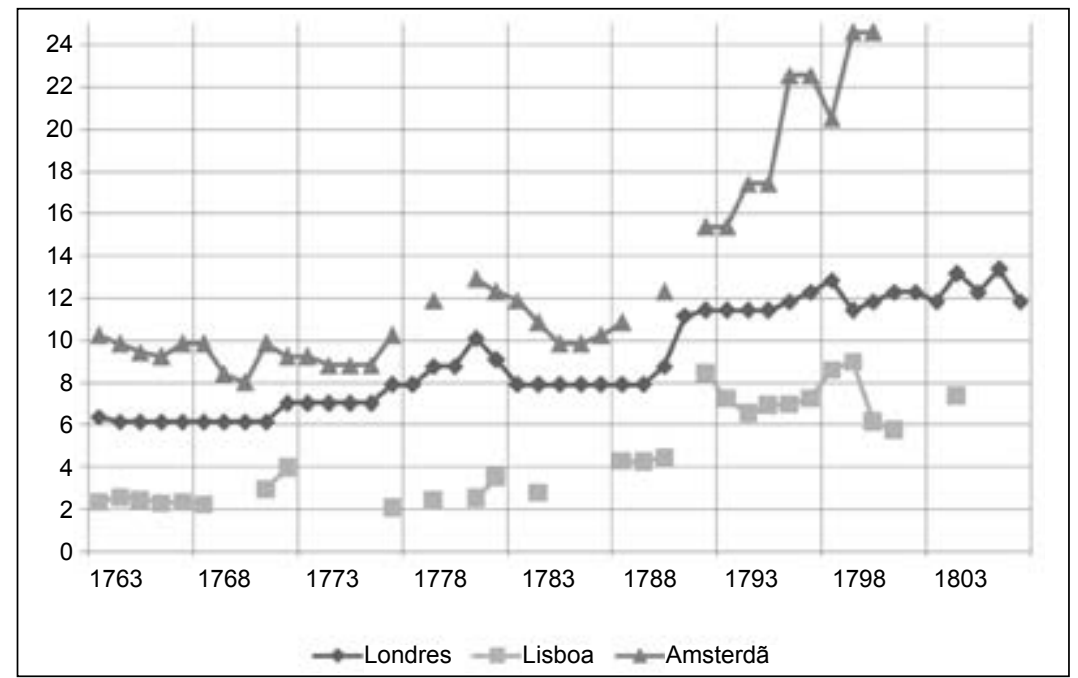

Fonte: PWR, GPIHG.

No Gráfico 8 podemos observar que, mesmo que não haja uma profunda correspondência entre os preços aferidos nas diferentes praças, percebemos certa similaridade nos movimentos das curvas entre as três localidades: período de queda a partir de 1738, seguido de recuperação até 1746 , bem como a alta observada no período de 1755 a 1759 e a queda a partir da década de 1760 , com tendência positiva após o ano de 1787.

A tendência do Gráfico 9 é de estabilidade e correspondência, uma vez que não existiam grandes variações entre os mercados, na primeira metade do século XVIII.Além disso, constata-se que Amsterdã e Londres competem em pé de igualdade nos preços do açúcar. Quando se observa os preços para esse primeiro recorte, notamos uma tendência de pouca flutuação destes para Londres, Amsterdã e Lisboa.

Notamos uma diminuição da similaridade nas curvas dos preços em relação a Lisboa e observamos um salto nos preços pagos em Amsterdã ao final da série, a partir de 1792 (Gráfico 10). Essa descolagem do mercado de Amsterdã pode ser causada pelas guerras associadas à Revolução Francesa, como, por exemplo, o processo da Revolução 
Haitiana. Mas não só. Também nessa época o açúcar das colônias britânicas era destinado exclusivamente para a Inglaterra (Pedreira, 1994, p. 53). Isso explica a diferença dos preços da Inglaterra para com os de Amsterdã. De vez que suficientemente abastecido o mercado interno, os mercadores britânicos não precisavam competir em mercados estrangeiros.

Se a similaridade com os dados relativos a Lisboa diminui - ainda que esse acompanhamento não seja possível devido às lacunas na fonte -, o mesmo não pode se dizer em relação aos dados aferidos nas outras duas praças analisadas, Londres e Amsterdã. De 1763 até 1790, as curvas se acompanham $^{7}$; a partir da década de 1790, os preços em Amsterdã disparam e podemos observar certa similaridade com o movimento de Lisboa, que demonstra certa recuperação a partir de 1795. Sinteticamente, as curvas gerais são: 1720-1738, estagnação com viés de queda; 1739-1749, ascendente; 1750-1771, estagnação com viés de queda; 1772-1781, ascendente; 1782-1807, estagnação seguida de alta.

Em resumo, não é possível afirmar que os preços no Brasil pudessem ser regulados pelos próprios produtores, configurando um sellers market ${ }^{8}$. Ao contrário, parece que a ideia mais clara, a partir dos dados, é de que os preços do açúcar seriam determinados externamente pelos mercados situados principalmente em Londres e Amsterdã. Mesmo que em alguns períodos não comprem açúcar produzido no Brasil, controlam os preços do gênero, pressionando os negociantes e influenciando diretamente as flutuações do mercado mundial do açúcar.

De certa forma, essa ideia, já apontada por Celso Furtado, pode ser comprovada ao analisarmos essas curvas de preços e a ligação destas com os ganhos reais da produção do açúcar, que se dava substancialmente nessas praças até a primeira metade do século XVIII.Assim, uma parcela

7 Tendo a diferença entre si nos valores aferidos de 1,5 grama a 2,9 gramas de prata por quilograma de açúcar, como mostra o Gráfico 8.

8 Menz aponta essa característica para o mercado dos grãos produzidos no Rio Grande do Sul e vendidos no Rio de Janeiro. Dada a falta de oferta desse gênero e a carestia de alimentos na capital, o mercado passaria então a ser controlado pelos produtores, caso inverso ao do açúcar em mais de um aspecto (Menz, 2009, p. 166). 
dos rendimentos que eram atribuídos aos senhores de engenho estaria localizada nas mãos dos não residentes, ou seja, fora da colônia (Furtado, 2007, p. 82). Essa hipótese, aliás, é demonstrada pela maior estabilidade dos preços em Lisboa, que se verifica no Gráfico 4.

Sobretudo, o que os últimos três gráficos $(8,9$ e 10) nos dizem é algo muito evidente. Os preços eram hierarquizados. Os maiores preços eram aqueles do Noroeste europeu, seguidos pelos de Lisboa e, por último, pelos das colônias. A determinação dos preços e sua inter-relação se encontram nessa evidência simples, e não tanto nas oscilações das curvas, sempre passíveis de imprecisão, mas, como demonstramos, elas possuem ritmos semelhantes, conclusão importante para a análise conjuntural que propomos fazer.

Nossa análise focou-se então nas alterações de cunho mais duradouro e naqueles momentos de maior vulto nas valorizações/quedas, e que se acompanham nas diferentes praças estudadas. A partir dos dados de que dispomos, conseguimos estabelecer em um primeiro período algumas relações de integração da Bahia nesse jogo mundial das determinações dos preços, o que também foi feito na segunda metade, dessa vez com o Rio de Janeiro. A percepção dessa hierarquização dos preços nos parece clara, ao passo que essas grandes variações expressadas no contexto dominante europeu, Londres e Amsterdã, se sente nos preços de Lisboa, que repassa essa pressão aos mercados da América Portuguesa, que, ao longo do século XVIII, integra novas regiões ao comércio de exportação não apenas no ramo da plantação da cana e do fabrico do açúcar, mas também nas atividades de apoio desta.

\section{O vil metal}

Ao lado do açúcar, a mineração foi fator importante para a economia colonial durante o Setecentos. Os valores aferidos com a sua extração fizeram com que o metal assumisse posição de destaque no contexto do século XVIII. Mesmo se levarmos em conta o pequeno tempo que durou seu boom exportador (aproximadamente de 1720-1750), as riquezas proporcionadas e as transformações na economia colonial foram imensas. A articulação de economias proporcionada pela mineração (Carrara, 2007, p. 17-18) nos coloca em face de algumas características 
especiais dessa atividade. $O$ fato de o ouro funcionar como moeda fez com que a economia colonial pudesse criar meios de ser polo de atração/demanda de mão de obra e ganhasse maior pujança em termos de mercado interno. A produção mineral sustentava e proporcionava a reprodução escravista na mineração:

É exatamente nesta dependência da circulação de uma moeda produzida na própria colônia, e não originária de uma demanda externa, que reside a especificidade da economia de Minas: a determinação última da atividade (e não economia) mineradora era absolutamente interna. Seu tempo de duração era determinado pela soma dos tempos de duração do conjunto das empresas. Isso quer dizer que o setor minerador não experimentou nenhuma dependência de oscilações de preços ou de demanda externa por seus produtos - ouro e pedras preciosas. (Carrara, 2007, p. 60)

A economia mineradora funcionava a partir de diferenciadas formas de extração: desde a pequena lavra até a produção em larga escala, utilizando mão de obra escrava. Assim, as lógicas - e os tempos - da atividade mineradora proporcionavam variadas ações decorrentes - desde a produção de alimentos até a reprodução da escravidão -, todas elas geradas a partir do caráter multiplicador da mineração, como bem frisou Angelo Carrara (Carrara, 2007, p. 60-64).

Assim como observamos na empresa açucareira, as atividades influenciadas pela mineração no contexto mais local de Minas Gerais - pecuária, agricultura etc. - são ligadas pelo vértice da escravidão. Também a criação pecuária, tanto de gado vacum, quanto de muares para transporte, a produção de gêneros alimentícios em condições de comportar o grande fluxo migratório para a capitania e mesmo a disponibilidade de novos oficios tornam-se elementos de primeira grandeza para o desenvolvimento da capitania. Mas é a reprodução do modo de produção escravista e sua sustentação que aparecem como o vetor do processo de desenvolvimento econômico aurífero e, por que não, colonial.

Dado seu caráter diferenciado em relação à produção, em que sua demanda respondia a um estímulo do rendimento das lavras, a reprodução do escravismo - subordinado à produção - se finda em decorrência do esgotamento das minas. O contrário ocorre nas regiões açucareiras, nas quais os estímulos são externos, determinantes da de- 
manda, subordinadores da produção e, por consequência, do sistema escravista em si. Por outro lado, nas franjas do modo de produção escravista, desenvolvem-se formas de produção camponesas que permitem um crescimento autônomo e relativamente independente da demografia colonial (Carrara, 2007, p. 66-67).

A integração de regiões antes pouco povoadas ou que não estavam completamente articuladas a um mercado interno de abastecimento, passa a incorporar a teia produtiva colonial. O sul da capitania de Minas Gerais, o oeste de São Paulo e o extremo Sul, com o Rio Grande de São Pedro, passam a interagir para o abastecimento, animados pela extração aurífera. Com suas produções em contínua integração, mesmo na decadência do ouro, persistiram abastecendo, por sua vez, também o mercado do Rio de Janeiro na segunda metade do século XVIII.

Um bom ponto de partida para nossa análise é verificar, em números gerais, como foi a performance do metal amarelo. Para isso, vejamos como se comporta a curva do rendimento geral do imposto do $1 \%$ do ouro (Gráfico 11).

Gráfico 11 - Remessas de ouro/imposto 1\%, 1720-1807 (em contos de réis)

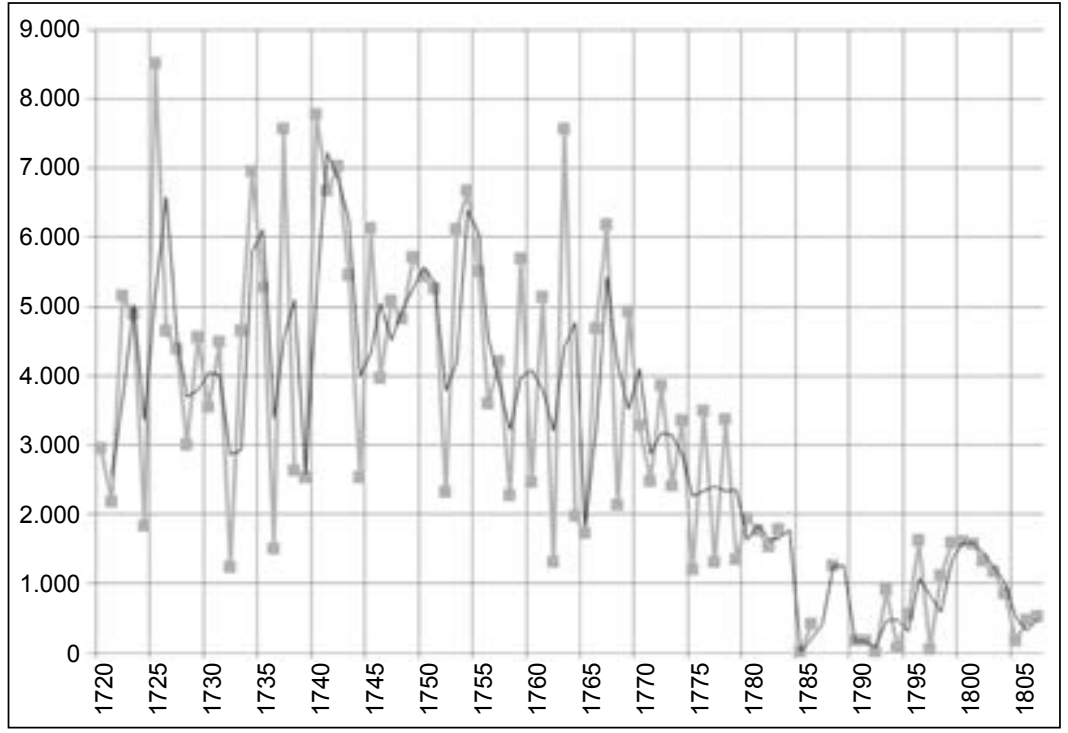

Fonte: Costa, Rocha e Sousa (2013). 
Ao regime das frotas atribuímos as grandes variações entre os valores anuais. Com o intuito de auxiliar na visualização, inserimos uma linha de tendência em médias móveis ${ }^{9}$ e percebemos uma clara tendência descendente, logo após 1767. Porém, a queda já se anunciava desde 1754. Vejamos agora esse gráfico transformado em índice, fragmentado em dois ${ }^{10}$, o primeiro dando conta de 1720 a 1762 e o segundo com o restante de nosso período, 1763 a 1807 :

Gráfico 12 - Remessas de ouro/imposto 1\%,1720-1762 (índice $1762=100$ )

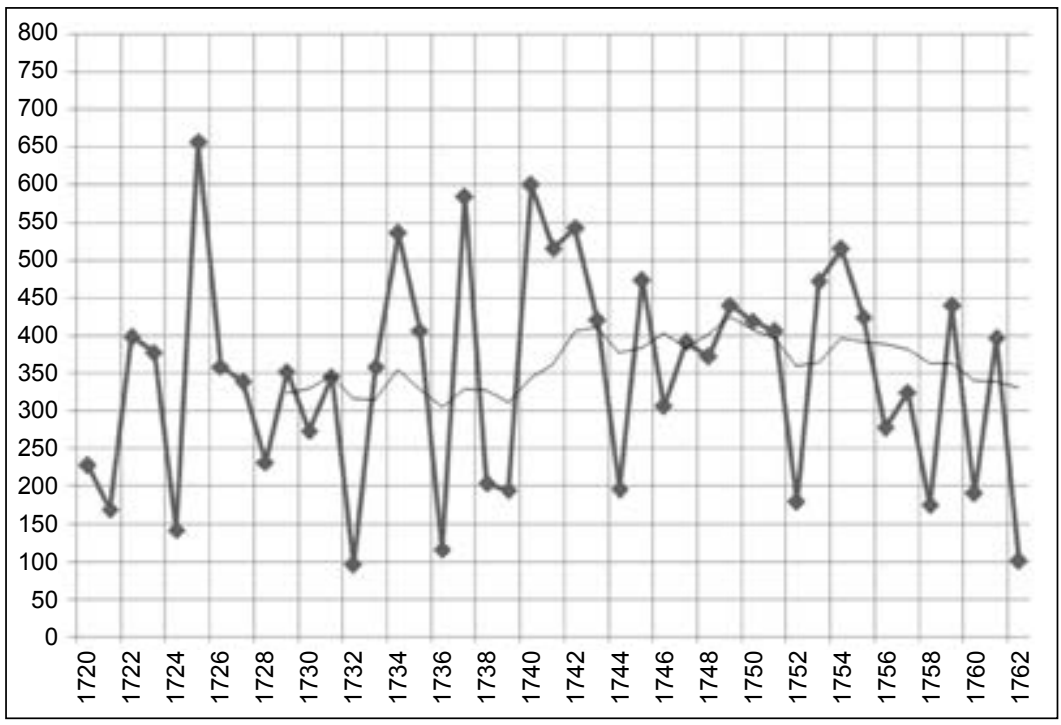

Fonte: Costa, Rocha e Sousa (2013).

No Gráfico 12 observamos alto patamar no índice de remessas, tendendo de certa forma a uma produção constante, se observarmos a linha tendencial inserida. Essa forma de análise por índices evidencia o período de queda que nossa data de referência está inserida, 1762, bem como mostra que a produção aurífera está sujeita a grandes variações de um lançamento a outro.Tal fato justifica a inserção da linha tendencial

\footnotetext{
$9 \quad$ Período $=2$.
}

10 Assim como no caso dos gráficos que apresentamos para a comparação do preço do açúcar nas praças europeias. 
de médias móveis ${ }^{11}$, para que possamos apreender o movimento tendencial do multiplicador de forma mais duradoura. O ponto de inflexão provocado pela marca referência do índice, ao final desse gráfico, evidencia esse auge produtivo, que conhecerá sua derrocada no período representado pelo gráfico seguinte:

Gráfico 13 - Remessas de ouro/imposto 1\%, 1763-1807 (índice 1762 = 100)

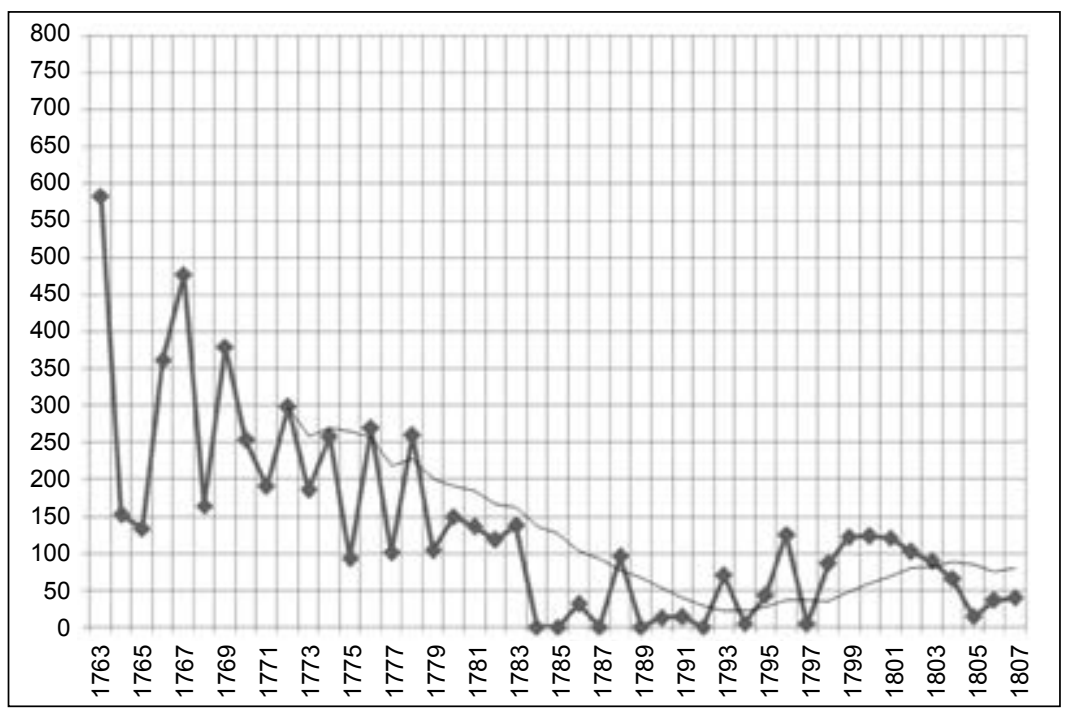

Fonte: Costa, Rocha e Sousa (2013).

A queda nas remessas de ouro se pronuncia em meados da década de 1750, chegando aos seus níveis mais baixos a partir da década de 1780 (Gráfico 13). O esgotamento dos veios auríferos em Minas Gerais remete a uma profunda desaceleração nos rendimentos dos dízimos, seguida por um período de estagnação. Interessante observar que, para além da derrocada da capitania de Minas Gerais, o ouro tinha, em seu movimento de escoamento pelos portos, certo efeito em outras capitanias, principalmente Rio de Janeiro e Bahia, esta última com produção própria um pouco tímida ${ }^{12}$. Sobre o movimento do transporte nos portos, podemos observar os diferentes patamares:

\footnotetext{
11 Agora com período mais largo, 10.

12 Existe um tópico específico sobre a produção baiana em Pinto (1979, p. 81-85).
} 
Gráfico 14 - Remessas de ouro/imposto 1\% provenientes da Bahia, de Pernambuco e do Rio de Janeiro, 1720-1807 (em contos de réis)

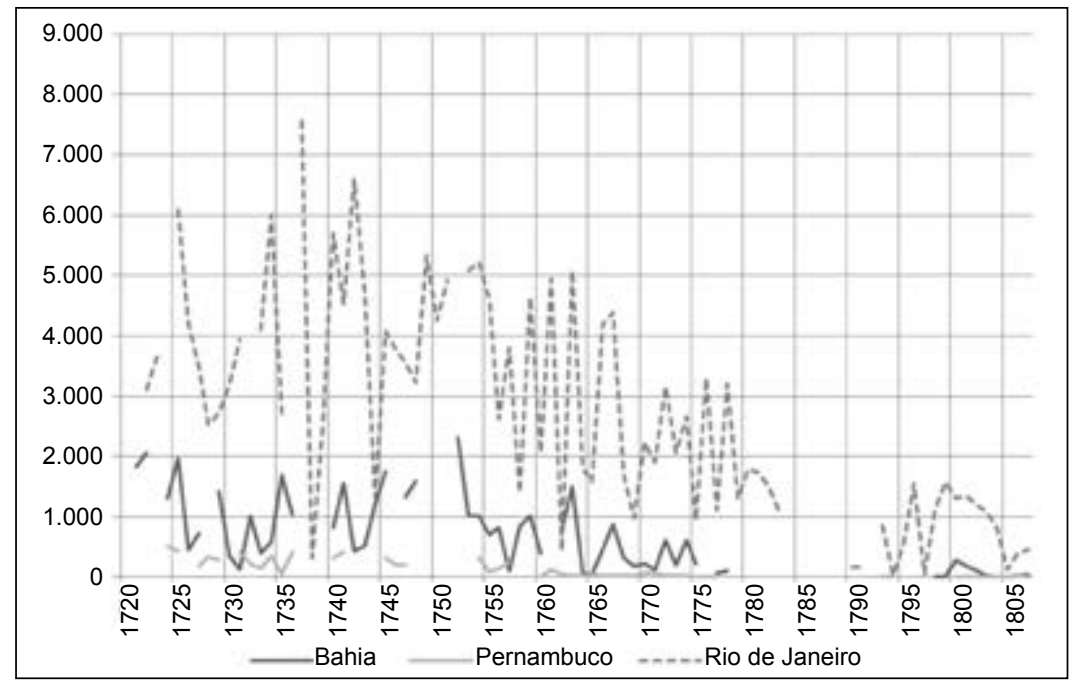

Fonte: Costa, Rocha e Sousa (2013).

Destarte, nossa atenção é apreendida com o fato de que o transporte substantivo das cargas do ouro se fazia por meio dos portos do Rio de Janeiro. A diferença nos montantes aferidos chega a ser de quase quatro vezes no ano de 1737, por exemplo, se compararmos as remessas do Rio de Janeiro em relação à Bahia. Importante destacar que esse domínio no escoamento, relacionado à proximidade geográfica entre a zona mineradora e o porto fluminense, pode explicar parcialmente a mudança do eixo econômico da colônia de Salvador para o Rio de Janeiro. Essa alteração pode ser identificada nas curvas dos dízimos. Não obstante, após o declínio da atividade mineradora, as remessas do Rio de Janeiro só experimentarão níveis tão baixos quanto os da Bahia somente no ano de 1786, quando caem abaixo dos 500 contos de réis, enquanto a queda na Bahia ocorre desde 1768, quando atingiu o patamar de 318 contos. Em Pernambuco o volume é ainda menor, nunca ultrapassando os 516 contos, caindo a níveis abaixo dos 100 contos de réis no início da década de 1760 .

Em linhas gerais, em relação às remessas de ouro durante o século XVIII (Gráfico 11), temos então: entre 1720 e 1737, a tendência é 
ascendente, destacando-se o auge no ano de 1725; entre 1738 e 1754, a tendência é de estagnação, contudo em alto patamar, na casa dos 4.000 contos; entre 1755 e 1769, nota-se uma tendência à queda, porém com médias consideráveis na casa dos 2.500 a 3.000 contos; já, entre 1770 e 1794, assistiu-se uma queda vertiginosa nas remessas de ouro; entre 1795 e 1807, houve uma tímida recuperação, não ultrapassando a casa dos 1.500 contos em 1801, seguindo novamente uma tendência negativa até 1807.

\section{A ascensão do primo pobre ${ }^{13}$}

Funcionando como espelho invertido da produção sacarina, a fumicultura demandava áreas normalmente descartadas para o plantio da cana - ou esgotadas por este - e se articulava às produções ligadas à subsistência e aos pequenos produtores. Sua configuração em relação aos tamanhos das plantações e condições do solo diferia frontalmente com o negócio da cana, o que de certa forma privilegiava os pequenos produtores. Fora isso, nas mesmas áreas onde o tabaco era cultivado, a mandioca também poderia ser plantada (Acioli, 2008, p. 97). Dessa forma, percebemos então como que as atividades produtivas dos espaços coloniais se complementam de forma coordenada. O tabaco se mostrou um gênero de suma importância nas articulações econômicas do Império, dada sua utilização no tráfico de escravos compondo uma cesta com os diferentes produtos demandados por ele, garantindo certas vantagens aos homens de negócios estabelecidos na colônia ${ }^{14}$, além de atender às demandas do próprio mercado europeu.Vejamos a flutuação dos valores das importações do tabaco no gráfico a seguir:

13 Tomamos emprestado o título de um artigo de Gustavo Acioli, publicado na revista Saeculum (Acioli, 2005).

14 "Portugueses reinóis, estabelecidos nos principais portos do Brasil, passaram a fazer tráfico com a África utilizando, no século XVII, gêneros da terra: cachaça e tabaco juntamente com as demais manufaturas demandadas em África." (Acioli, 2008, p. 84.) 
Gráfico 15 - Valor das importações na Alfândega do Tabaco de Lisboa (em contos de réis), $1720-1807 \star$

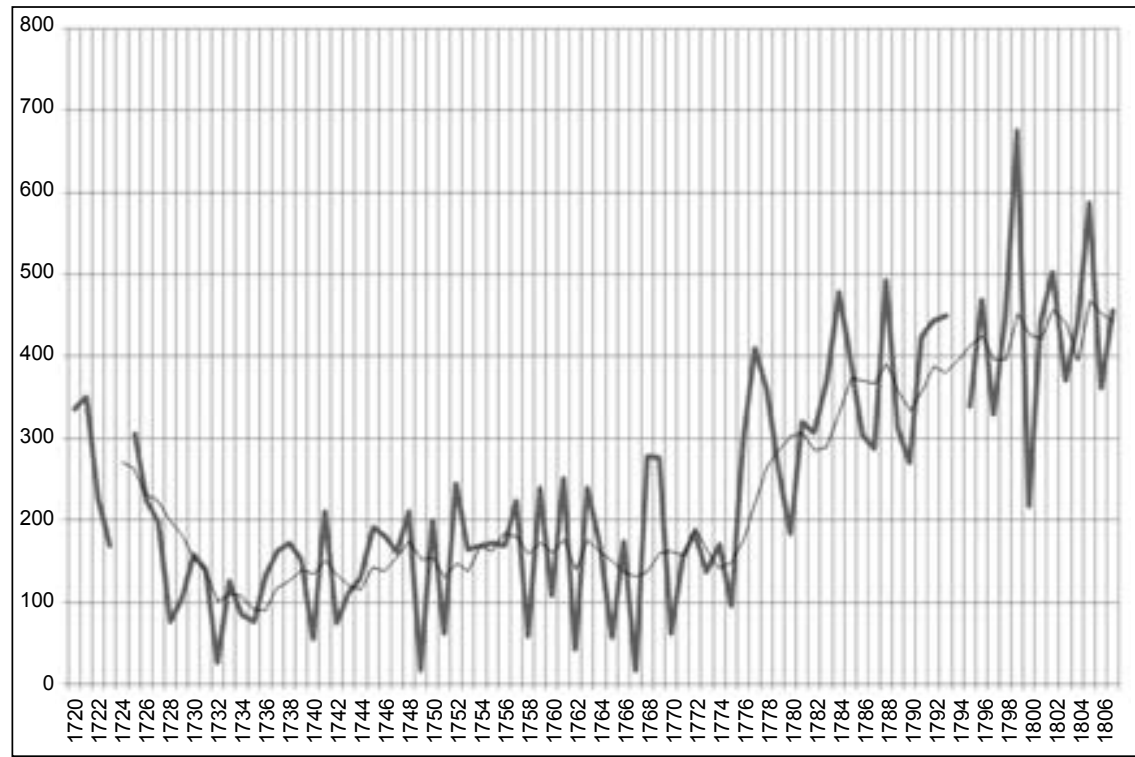

Fonte: Nardi (1996, Apêndice 1.1, p. 366-368; Apêndice 5.3, p. 405).

* Elaborado a partir dos dados de Nardi, utilizamos uma linha de médias móveis igual a cinco tanto para percebermos melhor as flutuações sem as oscilações tradicionais da variação das quantidades transportadas, quanto para seguir o próprio autor, que indica os preços de Lisboa em médias quinquenais. Para a elaboração do gráfico, utilizamos os dados do movimento de importação da Alfândega do Tabaco de Lisboa, donde o volume aferido refere-se ao fumo oriundo do Brasil, multiplicados pelo preço médio quinquenal de Lisboa. A escolha desse valor de preço se dá devido ao fato de que os preços da Bahia possuíam muitas lacunas e também por ocasião do comércio direto da Bahia com a Costa da Mina. Sendo assim, o montante aferido nos parece mais condizente com as relações entre os dados e para nosso fim, que é o de produzir mais um indicativo do movimento da economia atlântica.

No primeiro período, até 1732 , uma série de fatores influenciou a queda relativa nos montantes. Primeiramente, o próprio estabelecimento dos direitos de entrada e do monopólio ainda estava gerando efeitos negativos nos preços, o que desanimava os lavradores. Podemos levar em conta também a concorrência do fumo da Virgínia. Uma variação nos preços, de 1.350 para 900 réis, influenciou bastante essa queda no total. Essa fase descendente já havia sido identificada por Nardi desde o ano de 1699, a qual denominou de estagnação relativa (Nardi, 1996, p. 336-338).

A fase seguinte é marcada por altos e baixos, mas, a partir das médias, constata-se uma tendência à estagnação. Esta pode ter origens tanto na manutenção dos preços baixos da arroba, quanto na média de produção. 
Uma conjuntura de alta concorrência do fumo anglo-americano e de maior controle sobre a produção e comercialização (limitação de preços no Brasil, alta nos direitos em Lisboa) contribuiu para essa situação. E mesmo as medidas liberalizantes nas décadas de 1750-1760 terão seus efeitos apenas em meados de 1770 (Nardi, 1996, p. 342).

Podemos observar que o movimento do tabaco decola a partir do ano de 1776. Nesse ano, além do preço médio por arroba subir de 900 réis para 1.100 réis, as quantidades que chegam à Alfândega de Lisboa crescem em 100.000 arrobas. Nardi define esse período como "arrancada". Entre suas causas estaria a decadência do sistema colonial, o processo de independência dos Estados Unidos e as medidas tomadas na própria metrópole, como a abolição parcial do direito de entrada e a permissão de se importar fumo de menor qualidade para a Europa (Nardi, 1996, p. 342).

Assim como o açúcar, o tabaco se aproveitou do contexto causado pelos conflitos militares. O tabaco brasileiro (leia-se, baiano) desponta justamente no período de independência das 13 colônias americanas. Algo muito similar ao que aconteceu com o algodão. Não é à toa que, desde a segunda metade do século XVII, a produção fumageira já despertava interesses por parte da Coroa, tendo em vista que desde esse período houve esforços no sentido fiscal e de monopolização do comércio (Acioli, 2008, p. 93).

No reino, apesar das flutuações no primeiro quartel do século XVIII, o estanco do tabaco cresceu de forma significativa até 1755 , quando atingiu mais do que o dobro que se arrecadava em 1702 (Salvado, 2014, p. 144). A tendência geral do tabaco - tanto do lado da produção, quanto dos preços - foi de expansão acentuada a partir do terceiro quartel do Setecentos até a primeira década do século XIX, quando a partir de 1811 o volume das importações da Alfândega do Tabaco de Lisboa regride aos níveis pré- $1760^{15}$. Portanto, percebemos três movimentos claros nas flutuações da produção do fumo, ao longo do Setecentos: entre 1720 e 1727, de tendência descendente; entre 1728 e 1775, observamos uma estagnação; por fim, entre 1776 e 1807, há um movimento ascendente.

15 Nardi não desenvolve muitas linhas a respeito desse último período, chamado por ele de "Última fase (1808-1830)". Em linhas gerais, atribui essa queda no movimento da Alfândega do Tabaco de Lisboa a um incremento no comércio direto com a Costa da Mina principalmente no período pós-1815, no fluxo clandestino dada a proibição do tráfico de escravos (Nardi, 1996, p. 343). 


\section{A “instituição peculiar”}

Por fim, chegamos ao último, mas não menos importante, ponto de nossa análise das atividades coloniais definidoras desse século XVIII. Se pudéssemos apontar alguma delas como interconectada a todas as outras, esta reside na mão de obra e suas formas de obtenção: a escravidão. Entendemos a escravidão como uma instituição econômica de primeira grandeza, totalizante, definidora das relações sociais e econômicas, calcada na relação da produção mercantil dominante (Tomich, 2011, p. 52; Novais, 2005, p. 365).

Nas páginas que se seguem, procuraremos expor dados que aportem mais indícios e tendências dos movimentos conjunturais da economia colonial. Para isso, apresentamos os seguintes gráficos, que dão conta das importações gerais de escravos para as três localidades mais importantes da América Portuguesa: Bahia, Pernambuco e Rio de Janeiro, seguindo o padrão que temos estabelecido até aqui para as demais atividades. Essa análise está ligada às outras já apresentadas e procura complementar as hipóteses, principalmente acerca do comportamento das curvas do açúcar (gráficos 3 e 4, referentes à Bahia; gráficos 5 e 7, dando conta do Rio de Janeiro).

Podemos perceber que as importações seguem um ritmo ascendente, ainda que com grandes variações (Gráfico 16). No início do Oitocentos observamos seu auge, chegando a mais de 33.000 peças, mais do que o dobro de seus pontos mais baixos, experimentados abaixo da casa dos 15.000 escravos, nos anos de 1722 e 1777. Observemos a seguir um gráfico com esses dados desagregados, mostrando as curvas da Bahia, de Pernambuco e do Rio de Janeiro separadamente, e em seguida passamos à análise dos dados em visões individuais de cada movimento.

Analisando o Gráfico 17, comecemos pelas variações baianas.Vemos que a queda que resultou no segundo menor ponto da série se inicia após 1760 , mas as informações contidas no gráfico nos indicam essa tendência à queda desde ao menos 1750. Ao longo do século XVIII, houve uma dominância nas importações por duas praças: Bahia e Rio de Janeiro. Em um primeiro momento, a Bahia domina praticamente todos os anos. No momento seguinte, a partir da década de 1760, essa dominância passa para o Rio de Janeiro, explicitado pelo Gráfico 18. 
Gráfico 16 - Importações gerais de escravos (Bahia, Pernambuco e Rio de Janeiro agregados), 1720-1807

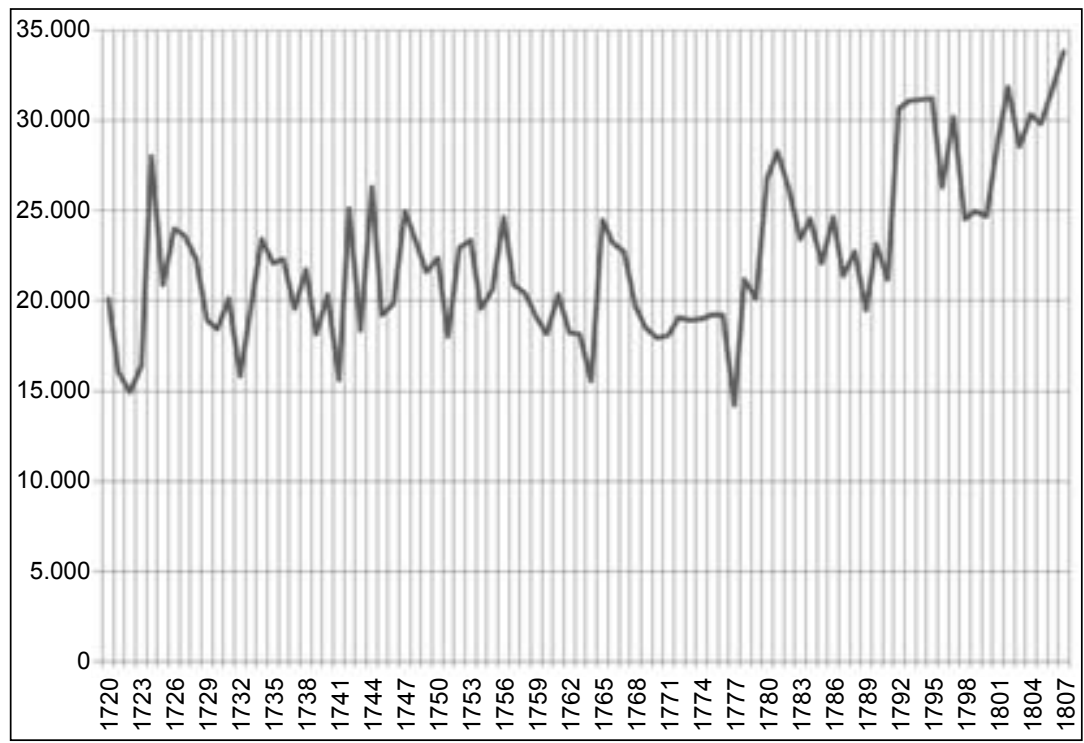

Fonte: Eltis (2008).

Gráfico 17 - Importações gerais de escravos (Bahia, Pernambuco e Rio de Janeiro), 1720-1807

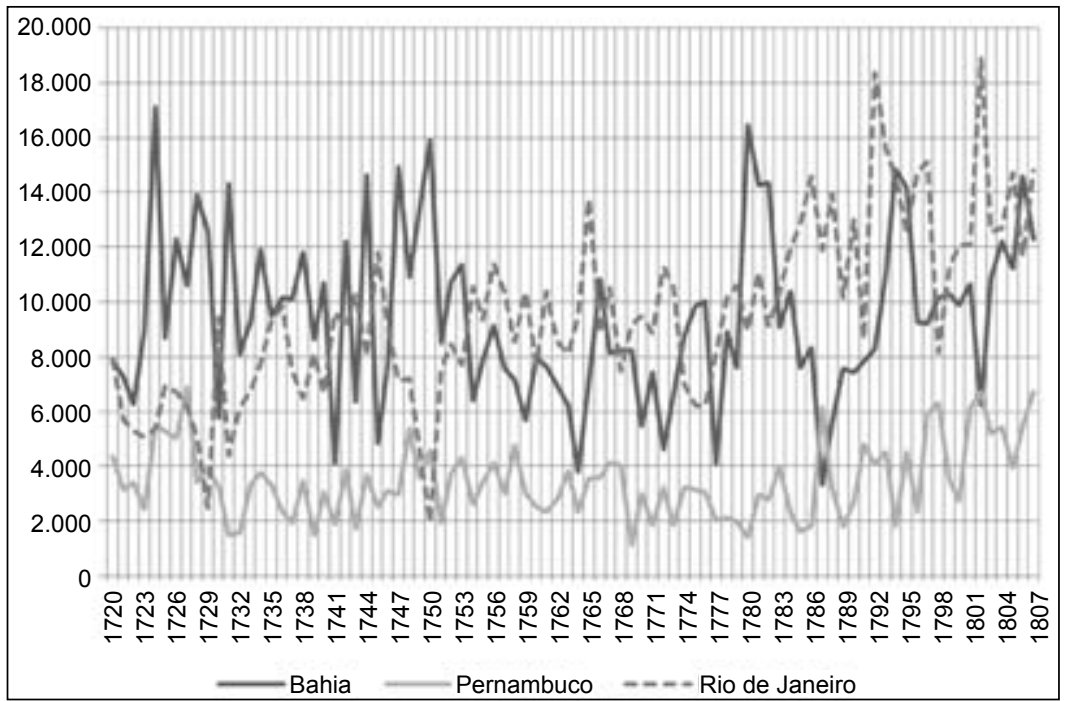

Fonte: Eltis (2008). 
Gráfico 18 - Importações gerais de escravos (Bahia, Pernambuco e Rio de Janeiro), 1720-1807 (por década)

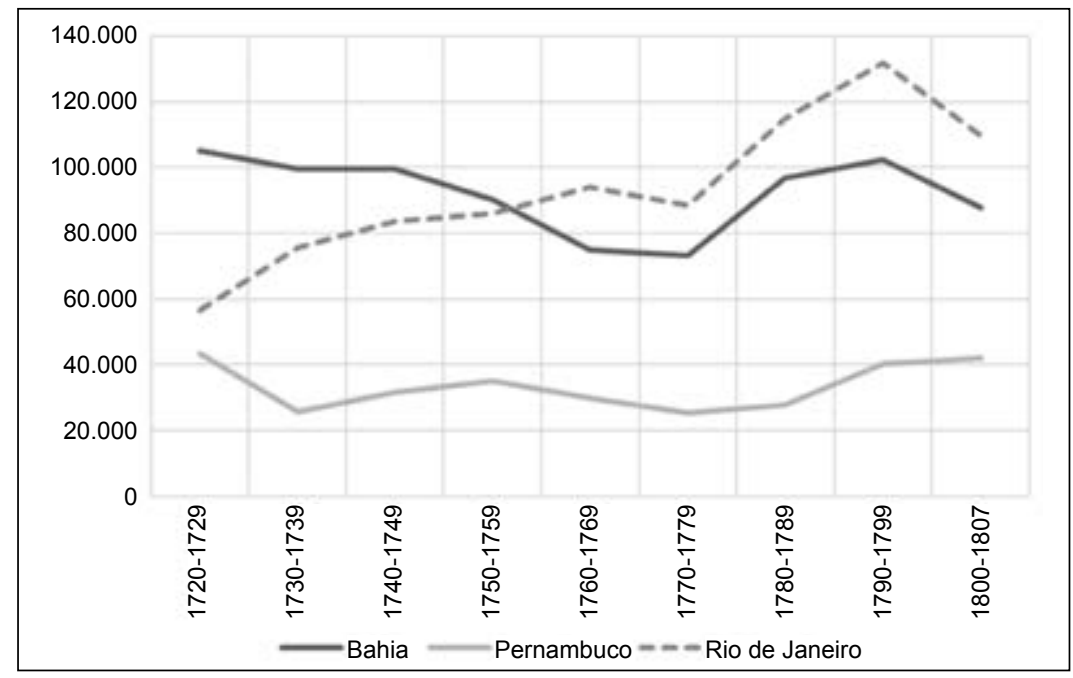

Fonte: Eltis (2008).

Sendo assim, temos os seguintes movimentos: 1720-1745, ascendente, seguido de leve tendência de queda; 1746-1764, movimento similar ao anterior, iniciando com uma tendência ascendente e, em seguida, descendente: até esse último movimento, mais precisamente até o ano de 1753, a Bahia liderava os números de importação de escravos, respondendo com aproximadamente $49 \%$ das importações, e no ano seguinte, respondendo com apenas 33\%, perde seu lugar para o Rio de Janeiro, que por sua vez chega à participação de $54 \%$ das peças entradas. Essa diferença poderia dar-se por uma diminuição geral das importações, o que de fato acontece, já que no ano de 1753 mais de 23.000 pessoas são importadas, ao passo que, no ano seguinte, apenas 19.523. Porém, a proeminência do Rio de Janeiro perdurará, tendo a Bahia o superado apenas em um ano nesse período, em 1760.

Já, em 1765-1776, houve leve estagnação com viés de alta, com a Bahia responsável pela maior contribuição em 1766 e 1768;1777-1794, alta aguda, começando em 1780 um período de três anos, em que a Bahia tomará novamente a dianteira das importações, passando por um movimento descendente com leve recuperação nos últimos seis anos; 
1795-1807, descendente, com leve estagnação: queda em 1802, mas recuperação e tendência de alta ao fim da série, e dois anos com a maior participação, 1798 e 1807.

A respeito de Pernambuco, verificamos que os níveis de importação de escravos se encontram bem abaixo dos aferidos na Bahia e no Rio de Janeiro. Observamos flutuações mais suaves. Analisando as conjunturas, temos que entre 1720 e 1731 há uma tendência negativa, sendo 1731 a menor participação da capitania nos percentuais totais de importação de escravos. Assistimos a uma estagnação entre os anos de 1732 e 1748. Entre 1749 e 1780 a estagnação continua, entretanto com viés de baixa. Por fim, de 1781 a 1807, mesmo com flutuações bruscas, a tendência é claramente de alta. Esse aumento das importações de escravos, assistido nesse período final, ajuda a entender a recuperação da produção do açúcar de Pernambuco, após o início dos conflitos para a independência do Haiti e, principalmente, com o fim da companhia monopolista de comércio, em 1780. Além do desenvolvimento da cultura algodoeira, que passa a representar as mais avultadas rendas da capitania também nesse período, a partir do terceiro quartel do século XVIII (cf. Ribeiro Júnior, 1981, p. 236-238).

Sendo assim, temos: 1720-1731, descendente, média de 20\% de participação nos primeiros anos, tendo o mínimo de 13\% em 1723, atingindo um maior patamar de $29 \%$ em 1727 , finalizando o período com viés descendente, com o ano de 1731 respondendo por um dos menores coeficientes de participação de Pernambuco nos totais, 7\%, média geral nesse período de 20\%; 1732-1748, média de participação de 14\%, estagnação, com viés de alta; 1749-1780, estagnação, com viés de baixa; 1781-1807, variações bruscas ano a ano, com tendência de alta, mesma média do período anterior, $15 \%$ de participação nos totais.

$\mathrm{O}$ caso do Rio de Janeiro é o que comporta a maior diferença entre o valor mínimo aferido e o máximo: 1.937 para 18.908. Alguns movimentos mais claros podemos depreender: alta do início da série até 1745 , seguida por uma brusca queda até 1750 , em que sua recuperação posterior sugere uma leve estagnação seguida por uma alta mais consistente até 1792 , sofrendo nova queda até 1798 . Em toda a série, a participação do Rio de Janeiro esteve na média dos $43 \%$, tendo seus menores valores entre 1747 e 1750, anos em que computa 29\%,31\%,22\% e 9\%, respectivamente. Nesses anos, ainda no período de dominância total da Bahia 
em relação às importações, devemos levar em conta um crescimento nas importações desta em relação aos anos anteriores, tendo dobrado seu número em relação a 1746.

De tal modo: 1720-1730, descendente, média ainda bem abaixo daquela que experimentará para a série, 28\%. O ano de 1730 é atípico, tendo uma alta bastante grande nas importações do Rio de Janeiro, em detrimento da queda dos números da Bahia; 1731-1745, ascendente, média de $40 \%$ de participação para o período, com 1731 respondendo pela participação mais baixa, 22\%, e 2 anos em que se alcançaram as maiores participações até então, 62\%, em 1741 e 1745; 1746-1772, inicia com queda aguda, contendo o pior ano da série, 1750, com 1.937 importações, seguido de recuperação. De certa forma, podemos apontar que os últimos 4 anos foram fundamentais na mudança do eixo das importações de escravos, invertendo-se da Bahia para o Rio de Janeiro. Nesse quadriênio, a média de participação situou-se em $42 \%$, e o ano de 1754 registra o maior número absoluto de peças importadas pelo Rio de Janeiro até então, 10.560. A maior parte, os últimos 17 anos, estagnação, com pico em 1765, maior média relativa dos períodos analisados até esse ponto, 48\%; 1773-1798, início descendente, acompanha-se uma queda geral das importações, até 1777 os números totais caem abaixo do patamar das 20.000 peças, quando se começa a perceber uma recuperação. Em números relativos, 1786 atinge 14.569 peças, 59\% dos totais. O último quadriênio é descendente, queda nos números absolutos do patamar de 14.000 peças, participação média de 53\%; 1792-1807, pico em 1792, seguido de queda abrupta até 1798. Ainda que esse primeiro período seja de queda nos números absolutos, parte-se de patamares muito altos, somando 99.079 peças importadas, encerrando-se a série com viés de alta, seguida de estagnação.

\section{Considerações finais}

Com a análise dos dados apresentados até este momento, percebemos um domínio, até meados da década de 1750, do que chamamos da região Norte - composta pela Bahia e por Pernambuco - sobre a região Sul capitaneada pelo Rio de Janeiro e por Minas Gerais. Essa mudança de eixo pôde ser observada no Gráfico 17, que trata da participação nas 
importações gerais de escravos. Já, em relação ao ouro de Minas Gerais, percebemos que foi através das remessas desse metal que o Rio de Janeiro se beneficiou e conseguiu se alcançar uma posição de destaque entre as capitanias da América Portuguesa. O impulso gerado pelo ouro na economia carioca não se esgotou com a decadência aurífera, pelo contrário, a economia do Rio de Janeiro se aproveitou (ou foi motor) da alteração institucional, tornando-se a capital do Estado do Brasil em 1763. Sendo assim, na segunda metade de nosso recorte, de 1763 a 1807, a dominação passou ao eixo Sul da colônia, com o Rio de Janeiro a capitanear a economia da América Portuguesa, e se sustenta como tal até o final de nosso recorte, como demonstrado nas curvas por década do Gráfico 18. O escoamento da produção aurífera pela Bahia, ainda que nunca tenha sido em altos patamares, experimenta de forma mais precoce a diminuição nos afluxos, com valores que serão apenas aferidos em finais da década de 1760, no Rio de Janeiro, onde o escoamento se dava de forma majoritária, qual ressaltado no Gráfico 14.

Assistimos a uma série de movimentos, que, ao final do século XVIII, apontam para uma recuperação geral da economia portuguesa no Atlântico. A variação negativa nas primeiras décadas de nosso recorte - influenciada pela queda no preço do açúcar nas décadas de 1730 e 1740 - é compensada pelo aumento da extração aurífera nesse mesmo período: esta atinge seu ápice no final da década de 1730, mantendo as altas remessas até inícios da década de 1750 . A recuperação dos preços do açúcar em Londres e Amsterdã se dá a partir de finais da década de 1730, algo que animou novamente a produção baiana, valorização sentida já no início da década seguinte, inclusive na metrópole, recuperando as perdas destas na relação com o ouro (gráficos 11, 9, 3 e 1).

O que pensamos estar claro em relação aos preços do açúcar é a relação de hierarquização entre as diferentes praças do mercado mundial. Capitaneadas por Amsterdã, que possui os maiores preços, e seguida por Londres, diferenças que pudemos perceber pela conversão dos valores ao equivalente comum, a prata. Em Lisboa, os preços sempre são menores, assim como os preços coloniais, que são pressionados pelos mercadores metropolitanos, tal qual explanado no Gráfico 8.

Completando o quadro, pudemos observar, com o auxílio do Gráfico 15, que, mesmo com os preços do tabaco estáveis em Lisboa, houve um incremento impressionante na produção do gênero a partir da década 
de 1770. Em termos conjunturais, existem indícios de que a América Portuguesa da segunda metade do século XVIII vale mais comercialmente, do que, mais ou menos, nos 30 anos anteriores.

\section{Bases de dados utilizadas}

GPIHG - Global Price and Income History Group, UC Davis. Disponível em < http:// gpih.ucdavis.edu/Datafilelist.htm>. Acesso em 27/5/2018. Planilhas: Brazil 15501769; VOC auction prices, quantities, and values traded, Amsterdam 1650-1790; England prices and wages since 13th; London and Southern England 1295-1914.

PWR - Prices, Wages and Rents in Portugal 1300-1910, Portuguese Foundation for Science and Technology (FCT). Disponível em <http://pwr-portugal.ics.ul.pt/>. Acesso em 27/5/2018. Planilhas: Honey and sugar; tobacco; Price of silver; Coin equivalences.

\section{Referências bibliográficas}

ACIOLI, Gustavo.A ascensão do primo pobre: o tabaco na economia colonial na América Portuguesa - um balanço historiográfico. Saeculum. João Pessoa, jan.-jun. 2005.

ACIOLI, Gustavo. Negócio da Costa da Mina e comércio atlântico - tabaco, açúcar, ouro e tráfico de escravos: Pernambuco (1654-1760). São Paulo: USP, 2008 (Tese de Doutorado).

ARRUDA, José Jóbson de Andrade. Superlucros: a prova empírica do exclusivo colonial. Topoi. Rio de Janeiro, v. 15, n. 29, p. 706-718, jul.-dez. 2014.

BARICKMAN, B. J. Um contraponto baiano: açúcar, fumo, mandioca e escravidão no Recôncavo, 1780-1860. Rio de Janeiro: Civilização Brasileira, 2003.

CARRARA, Ângelo. Minas e currais: produção rural e mercado interno em Minas Gerais, 1674-1807. Juiz de Fora: Editora UFJF, 2007.

COSTA, Leonor Freire; ROCHA, Maria Manuela; SOUSA, Rita Martins de. O ouro do Brasil, 1700-1807. Lisboa: Imprensa Nacional - Casa da Moeda, 2013.

ELTIS, David et al. Voyages: the trans-Atlantic slave trade database, 2008. Disponível em <www.slavevoyages.org>. Acesso em 16/5/2018.

FERLINI,Vera Lucia Amaral. Açúcar e colonização. São Paulo: Alameda, 2010.

FURTADO, Celso, Formação econômica do Brasil. 34. ed. São Paulo: Companhia das Letras, 2007.

JOHNSON JR., Harold. A preliminary inquiry into money, prices, and wages in Rio de Janeiro, 1763-1823. In: ALDEN, Dauril (org.). Colonial roots of modern Brazil. Berkeley: University of California Press, 1973, p. 274-276.

LAPA, José Roberto do Amaral. A Bahia e a carreira da Índia. São Paulo: Companhia Editora Nacional, 1968. 
MENZ, Maximiliano M. Entre Impérios: formação do Rio Grande na crise do antigo sistema colonial português (1777-1822). São Paulo: Alameda, 2009.

MENZ, Maximiliano M. Reflexões sobre duas crises econômicas no Império português (1688-1770). Varia História. Programa de Pós-Graduação em História, Faculdade de Filosofia e Ciências Humanas, Universidade Federal de Minas Gerais, v. 29 n. 49, p. 35-54, jan.-abr. 2013.

NARDI, Jean Baptiste. O fumo brasileiro no período colonial. São Paulo: Brasiliense, 1996.

NOVAIS, Fernando. A proximações. Estudos de história e historiografia. São Paulo: Cosac Naify, 2005.

PEDREIRA, Jorge. Estrutura industrial e mercado colonial. Portugal e Brasil (1780-1830). Lisboa: DIFEL, 1994.

PINTO,Virgílio Noya. O ouro brasileiro e o comércio anglo-português. São Paulo: Companhia Editora Nacional, 1979.

RIBEIRO JÚNIOR, José. A economia algodoeira em Pernambuco: da colônia à Independência. Revista Brasileira de História. São Paulo, 1, 2, p. 235-242, set. 1981.

SALVADO, João Paulo. O estanco do tabaco em Portugal: contrato geral e consórcios mercantis (1702-1755). In: LUXÁN, Santiago de. Política y hacienda del tabaco en los Imperios ibéricos (siglos XVII-XIX). Madrid: Centro de Estudios Políticos y Constitucionales, 2014, p. 133-153.

SCHWARTZ, Stuart B. Escravos, roceiros e rebeldes. Bauru: EDUSC, 2001.

TOMICH, Dale W. Pelo prisma da escravidão: trabalho, capital e economia mundial.Trad. Antonio de Pádua Danesi. Rev. téc. Rafael de Bivar Marquese. São Paulo: Editora da Universidade de São Paulo, 2011. 